\title{
MINERAL PROFILE OF THE WINTER WHEAT GRAIN: EFFECTS OF SOIL TILLAGE SYSTEMS AND NITROGEN FERTILIZATION
}

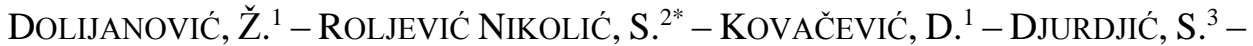 \\ MiodRAGOVIĆ, R. ${ }^{3}$ - JOVANOVIĆ TODOROVIĆ, M. ${ }^{2}$ - POPOVIĆ DJORDJEVIĆ, J. ${ }^{*}$ \\ ${ }^{I}$ Department of Field and Vegetable Crops, Faculty of Agriculture, University of Belgrade, \\ St. Nemanjina 6, 11080, Belgrade, Serbia \\ (phone: +381-11-441-3321) \\ ${ }^{2}$ Institute of Agricultural Economics, Belgrade, St. Volgina 15, 11060 Belgrade, Serbia \\ (phone: +381-11-697-2842, fax: +381-11-697-2848) \\ ${ }^{3}$ Department for Agricultural Engineering, Faculty of Agriculture, University of Belgrade, \\ St. Nemanjina 6, 11080, Beograd, Serbia \\ (phone: +381-11-441-3449) \\ ${ }^{4}$ Department of Food Technology and Biochemistry, Faculty of Agriculture, University of \\ Belgrade, St. Nemanjina 6, 11080, Belgrade, Serbia \\ (phone: +381-11-441-3142) \\ *Corresponding authors \\ e-mail: svetlana_r@iep.bg.ac.rs (S. Roljević Nikolić, ORCID ID: 0000-0002-3139-0289); \\ jelenadj@agrif.bg.ac.rs (J. Popović Djordjević, ORCID ID: 0000-0003-4057-3826)
}

(Received 22 $2^{\text {nd }}$ Apr 2019; accepted 12 $2^{\text {th }}$ Jul 2019)

\begin{abstract}
The aim of this study was to analyze the impact of various systems of soil tillage and nitrogen doses on the mineral composition of the grain of the common winter wheat cultivar (Triticum aestivum ssp. vulgare), cv. Azra selected for the conventional intensive production. The field experiment was conducted on luvic chernozem in completely randomized blocks. Wheat was grown under three soil tillage systems: conventional tillage, mulch tillage and no-tillage, and the experiment included two doses of $\mathrm{N}$ fertilization (60 and $120 \mathrm{~kg} \mathrm{ha}^{-1}$ ). Concentrations of eighteen elements (As, $\mathrm{Al}, \mathrm{Ba}, \mathrm{Ca}, \mathrm{Co}, \mathrm{Cr}, \mathrm{Cu}$, $\mathrm{Fe}, \mathrm{Hg}, \mathrm{K}, \mathrm{Mg}, \mathrm{Mn}, \mathrm{Ni}, \mathrm{S}, \mathrm{Sr}, \mathrm{P}, \mathrm{V}$ and $\mathrm{Zn}$ ) in wheat grain samples were determined by means of inductively coupled plasma with optical emission spectrometry (ICP-OES). The results indicated that concentrations of the studied elements in the wheat grain were significantly affected by the tillage systems and fertilization rates $(\mathrm{p}<0.001)$, as well as by the interaction of these two factors. A smaller dose of nitrogen fertilizer ( $\left.60 \mathrm{~kg} \mathrm{ha}^{-1}\right)$ had a significantly better impact on the concentration of macro- and microelements in the wheat grain than the dose of $120 \mathrm{~kg} \mathrm{~N} \mathrm{ha}^{-1}$. The reduced tillage systems and lower nitrogen rates in nutrition had a better effect on the increase of the content of the studied elements in the wheat grain than the conventional cultivation which applied higher nitrogen rates.
\end{abstract}

Keywords: wheat grain, production system, fertilization, macroelements, microelements, ICP-OES

\section{Introduction}

Wheat (Triticum aestivum L.) is one of the most significant cultivated species and the staple food for more than 50\% of the global population (Rizwan et al., 2016). The average per capita consumption of wheat in developed countries and developing countries amounts to $95 \mathrm{~kg}$ and $61 \mathrm{~kg}$, respectively (FAO, 2016). In Serbia, the average per capita consumption of wheat is $180 \mathrm{~kg}$, which is significantly higher than the consumption rates in most European countries (USDA, 2017). Due to its high global 
consumption in the form of different food products, wheat is considered to be an important source of minerals in the everyday human nutrition.

The bioavailability of microelements in cereals is generally low (Kan, 2015; Dapkekar et al., 2018) and the concentrations of trace elements that are valuable for human nutrition steadily decrease with an increase in yield, which has adverse consequences, including 'hidden hunger' (Cakmak et al., 2010). Approximately half of the global population has zinc deficiency, and anaemia induced by iron deficiency is the most common phenomenon in Europe (Kan, 2015; Winiarska-Mieczan et al., 2019). In this context, the increase of micronutrient concentrations such as $\mathrm{Fe}$ and $\mathrm{Zn}$ in cereal grain has become a high-priority research area (Cakmak et al., 2010; Kutlu, 2018). Certain heavy metals $(\mathrm{Zn}, \mathrm{Cu}$ and $\mathrm{Ni}$ ) are necessary for biological processes in the human organism and they represent integral and catalytic components of proteins and enzymes, but they can be toxic in an overdose (Tiwari and Lata, 2018). On the other hand, toxic or non-essential elements such as $\mathrm{As}, \mathrm{Cd}, \mathrm{Cr}$ and $\mathrm{Pb}$ have no biological function in the human body and can be harmful for human health even in extremely low concentrations in case of long-term exposure (Lei et al., 2015; Zhang et al., 2019). What is more, these metals are responsible for the depletion of certain essential elements (Abbas et al., 2017).

The optimal application of fertilizers is an important factor for obtaining high yield and high quality products. Among the elements of mineral nutrition, nitrogen has the most important role in forming the yield (Litke et al., 2018), quality and utilizable value of the wheat grain (Blandino et al., 2016). Numerous studies have shown that the application of nitrogen fertilizer can promote the accumulation of certain microelements in the wheat grain, such as Fe and Zn (Kutman et al., 2011; Singh et al., 2018). This effect is explained by the fact that the sufficient supply of nitrogen increases the content of proteins in the grain, and the proteins are where $\mathrm{Fe}$ and $\mathrm{Zn}$ are accumulated (Barunawati et al., 2013). Similarly, previous research has shown that the concentration of $\mathrm{Fe}$ and $\mathrm{Zn}$ has a significant positive correlation with the content of proteins and $\mathrm{P}$ in the wheat grain (Zhao et al., 2009).

There has recently been an increasing interest in reduced soil tillage, stimulated by ecological and economic reasons (Sharma et al., 2011). According to some authors, the methods of reduced soil tillage increase soil density and inadequate distribution of nitrogen, phosphorus and microelements (Klikocka and Marks, 2018), which can consequently affect the uptake of mineral matter and thus influence the yield and crop quality. However, Stanislawska-Glubiak and Korzeniowska (2012) did not determine significant differences between various tillage systems regarding the content of microelements in wheat plants, except in respect of $\mathrm{P}$ and $\mathrm{Mg}$ in the early growth phases when the concentration of these elements was higher in the NT and MT systems than in CT. A similar study indicated that the NT system did not lead to the impairment of the quality of wheat and maize grains in terms of the primary mineral content, which is extremely significant for the nutritional value of the wheat grain (Stanisławska-Glubiak and Korzeniowska, 2012).

Scientific literature is still deficient in information regarding the impact of tillage on the chemical content of the wheat grain. Thus, the aim of this research was to determine the impact that tillage systems and different fertilization rates, within the applied cultivation technology, had on the differences in the content of the studied elements in the wheat grain of the cultivar Azra. 


\section{Materials and methods}

\section{Field experiment}

The examination of the effects of different tillage systems and fertilization rates on the content of macro- and microelements in the wheat grain was conducted at the research field "Radmilovac" that belongs to the Faculty of Agriculture $\left(44^{\circ} 45^{\prime} \mathrm{N}\right.$, $20^{\circ} 35^{\prime}$ E, Serbia) in the growing season of 2016-2017. The soil type was luvic chernozem (WRB, 2014), with the following characteristics: $\mathrm{pH}_{(\mathrm{H} 2 \mathrm{O})} 8.04$, total content of $\mathrm{N} \mathrm{13 \%}$, available forms of phosphorus $22.18 \mathrm{mg}_{2} \mathrm{O}_{5} 100 \mathrm{~g}^{-1}$ dry weight and potassium $19.10 \mathrm{mg} \mathrm{K}_{2} \mathrm{O} 100 \mathrm{~g} \mathrm{~g}^{-1} \mathrm{dw}$, content of humus in the topsoil layer $2.45 \%$.

The study used the winter cultivar of common wheat (Triticum aestivum ssp. vulgare), cv. Azra, selected for the conventional intensive production. Cv. Azra is a winter hardy cultivar of medium late maturity. It is very well-resistant to Erysiphe graminis DC. and well-resistant to Puccinia striiformis f. sp. tritici (Pst). Its hectolitre weight amounts to $80-85 \mathrm{~kg}$, protein content is $11.5-13.0 \%$, and it belongs to the B1B2 quality group. The previous crop was maize (Zea mays L.).

A two-factor field trial was arranged using split plot design in three replications, with the area of the elementary plot amounting to $6 \mathrm{~m}^{2}$. The examined factors were tillage and fertilization. Three different tillage systems were used and two levels of fertilization were applied (Fig. 1).

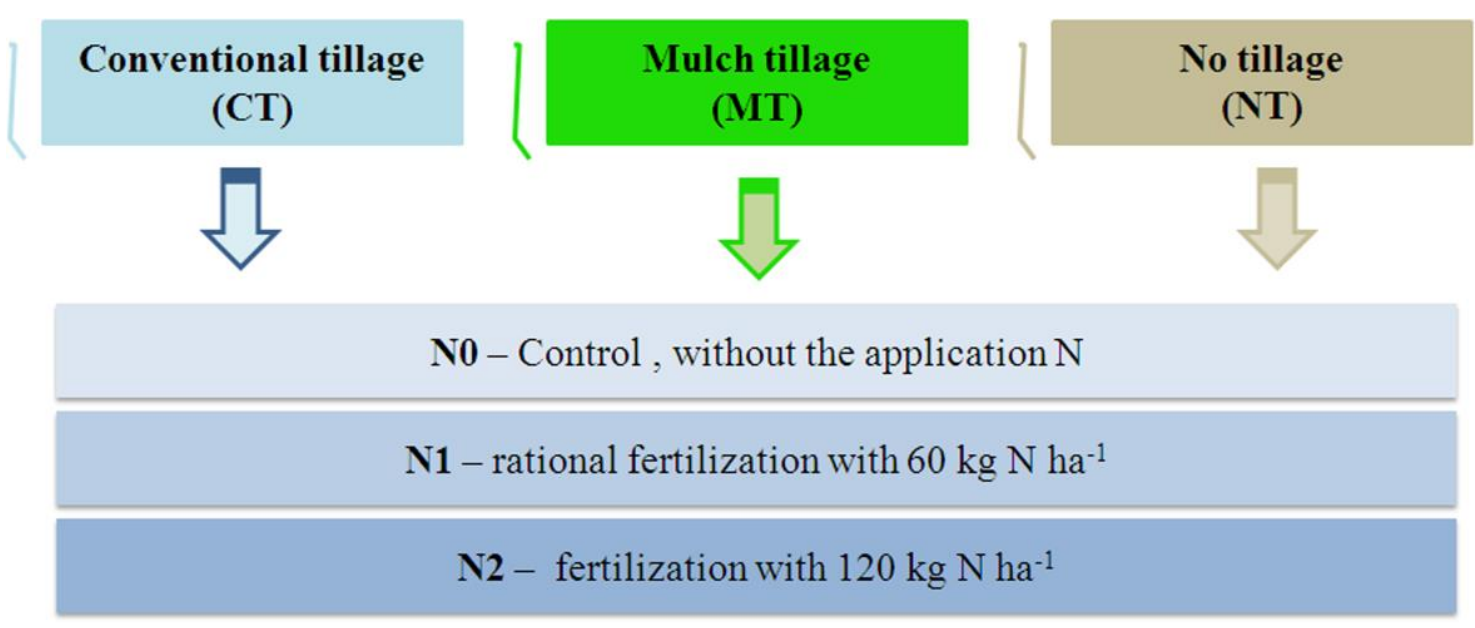

Figure 1. Experiment design

1. Conventional tillage (CT) - ploughing using a mouldboard plough at $25 \mathrm{~cm}$ and pre-sowing tillage using a disc harrow and a harrow,

2. Mulch tillage (MT) - tillage performed using a chisel plough at $25 \mathrm{~cm}$ with more than $30 \%$ of maize crop residues on the soil surface and the pre-sowing tillage using a disc harrow and a harrow,

3. No tillage (NT) - seeds were sown directly into unploughed soil, with the complete maize crop residues left on the surface.

Basic fertilization by NPK fertilizers was conducted during the autumn in the same quantity for all treatments. Spring fertilization was performed in the tillering phase using the KAN mineral fertilizer $(25-27 \% \mathrm{~N})$ and it differed in terms of pure nitrogen 
quantities. Sowing was conducted on October $28^{\text {th }}, 2016$ with the crop density of 650 seeds $\mathrm{m}^{-2}$. Standard cultivation measures in wheat production were applied and harvest was performed on June $29^{\text {th }}, 2017$.

\section{Grain sample preparation for chemical analysis}

In the grain of Azra cultivar, concentrations of macroelements: calcium $(\mathrm{Ca})$, potassium $(\mathrm{K})$, magnesium $(\mathrm{Mg})$, phosphorus $(\mathrm{P})$ and sulphur $(\mathrm{S})$, as well as microelements: aluminium (Al), arsenic (As), barium $(\mathrm{Ba})$, cobalt $(\mathrm{Co})$, chromium $(\mathrm{Cr})$, copper $(\mathrm{Cu})$, iron $(\mathrm{Fe})$, mercury $(\mathrm{Hg})$, manganese $(\mathrm{Mn})$, nickel $(\mathrm{Ni})$, strontium $(\mathrm{Sr})$, vanadium $(\mathrm{V})$ and zinc $(\mathrm{Zn})$ were determined.

The representative samples were made using a random square method as described by Korunović and Stojanović (1989). The wheat grain samples were ground in the laboratory mill SJ-500 (producer "Metron"), and then prepared for the chemical analysis. Both soil and grain samples were subjected to the process of "wet digestion" as described in our previous work (Popović-Djordjević et al., 2019).

The determination of the content of the elements was performed using the inductively coupled plasma-optical emission spectroscopy (ICP-OES) analysis. The analysis was conducted using the instrument Thermo Scientific iCAP 6500 Duo ICP (Thermo Fisher Scientific, Cambridge, UK). The calibration of the instrument was performed by means of two certified multielement ICO-OES standards: Multi-Element Plasma Standard Solution 4, Specpure ${ }^{\circledR}$ (Alfa Aesar GmbH \& Co KG, Germany) and SS-Low Level Elements ICV Stock (10 mg L-1K) (VHG Labs, Inc-Part of LGC Standards, Manchester, NH 03103 USA). The analytic process was verified by the certified reference material EPA Method 200.7 LPC Solution (ULTRA Scientific, USA). The correlation of the measured concentrations with the certified values amounted to $96-104 \%$.

\section{Statistical analysis}

Data processing was performed in the SPSS statistical package. The method for analyzing the variance ( $F$ test) for dual factor examination was used, and the significance of differences between the treatments was tested with the LSD test at the significance level of $\mathrm{p}<0.05$. Statistical data are given in Table Al in the Appendix.

\section{Results}

\section{Concentration of macroelements in the wheat grain}

The total content of the examined macroelements, as well as their average values are presented in Table 1. The total content of macroelements detected in the NT system $\left(9968.11 \mathrm{mg} \mathrm{kg}^{-1}\right)$ was higher $(\mathrm{p}<0.05)$ than in the MT and CT systems, by $1.7 \%$ and $5.3 \%$, respectively. Differences in the treatment by means of nitrogen fertilization were also significant, where the content of macroelements in the control $\left(9968.11 \mathrm{mg} \mathrm{kg}^{-1}\right)$ was higher by 2.3 and $3.2 \%$ than at the $\mathrm{N} 1$ and $\mathrm{N} 2$ levels, respectively.

The concentration of the examined macroelements, expressed in $\mathrm{mg} \mathrm{kg}^{-1}$, was in the following order: $\mathrm{P} \quad(4058.89)>\mathrm{K} \quad(3350.33)>\mathrm{Mg} \quad(1169.55)>\mathrm{S} \quad(996.89)>\mathrm{Ca}$ (171.33). The analysis of variance showed the statistically significant variability of macroelement concentrations among the studied tillage systems, as well as among the rates of nitrogen fertilization (Table A1). Considering the differences in the tillage 
systems, the results indicate that the lowest concentration of all studied macroelements was detected in the CT system. The highest concentration of $\mathrm{Ca}\left(178.67 \mathrm{mg} \mathrm{kg}^{-1}\right), \mathrm{K}$ (3410.33 mg kg-1), Mg (1236.33 $\mathrm{mg} \mathrm{kg}^{-1}$ ) and $\mathrm{P}\left(4167.00 \mathrm{mg} \mathrm{kg}^{-1}\right)$ was detected in the NT system, while the highest concentration of $\mathrm{S}\left(1016.33 \mathrm{mg} \mathrm{kg}^{-1}\right)$ was found in the MT system.

Table 1. Concentration of macroelements $\left(\mathrm{mg} \mathrm{kg}^{-1}\right)$ in the wheat grain, $\mathrm{cv}$. Azra

\begin{tabular}{c|c|c|c|c|c|c|c}
\hline Tillage & N Rate & Ca & K & Mg & P & S & $\begin{array}{c}\text { Total content of } \\
\text { macroelements }\end{array}$ \\
\hline \multirow{3}{*}{ CT } & N0 & $164 \pm 2$ & $3652 \pm 34$ & $1300 \pm 7$ & $4470 \pm 14$ & $1031 \pm 1$ & 10617.00 \\
& N1 & $173 \pm 4$ & $3244 \pm 24$ & $1094 \pm 14$ & $3917 \pm 12$ & $965 \pm 6$ & 9393.00 \\
& N2 & $141 \pm 2$ & $2926 \pm 22$ & $942 \pm 26$ & $3388 \pm 17$ & $983 \pm 6$ & 8380.00 \\
\hline \multirow{3}{*}{ MT } & N0 & $165 \pm 3$ & $3287 \pm 32$ & $1139 \pm 27$ & $3973 \pm 22$ & $981 \pm 6$ & 9545.00 \\
& N1 & $177 \pm 3$ & $3462 \pm 34$ & $1180 \pm 27$ & $4180 \pm 19$ & $1040 \pm 5$ & 10039.00 \\
& N2 & $186 \pm 2$ & $3351 \pm 11$ & $1162 \pm 23$ & $4101 \pm 4$ & $1028 \pm 3$ & 9828.00 \\
\hline \multirow{3}{*}{ NT } & N0 & $189 \pm 4$ & $3271 \pm 26$ & $1192 \pm 11$ & $4007 \pm 17$ & $954 \pm 3$ & 9613.00 \\
& N1 & $178 \pm 3$ & $3333 \pm 33$ & $1158 \pm 6$ & $4023 \pm 10$ & $979 \pm 2$ & 9671.00 \\
& N2 & $169 \pm 3$ & $3627 \pm 11$ & $1359 \pm 4$ & $4471 \pm 9$ & $1011 \pm 2$ & 10637.00 \\
\hline \multirow{3}{*}{ Tillage } & CT & 159.33 & 3274.00 & 1112.00 & 3925.00 & 993.00 & 9463.33 \\
& MT & 176.00 & 3366.67 & 1160.33 & 4084.67 & 1016.33 & 9804.00 \\
& NT & 178.67 & 3410.33 & 1236.33 & 4167.00 & 981.33 & 9968.11 \\
\hline \multirow{3}{*}{ N Rate } & N0 & 172.67 & 3403.33 & 1210.33 & 4150.00 & 988.67 & 9925.00 \\
& N1 & 176.00 & 3346.33 & 1144.00 & 4040.00 & 994.67 & 9701.00 \\
& N2 & 165.33 & 3301.33 & 1154.33 & 3986.67 & 1007.33 & 9615.00 \\
\hline
\end{tabular}

Data are expressed as mean \pm standard deviation $(n=3)$

The concentration of macroelements in the grain significantly varied depending on different levels of nitrogen fertilization (Tables 1 and $A 1$ ). In the control group, there was a significantly higher concentration of $\mathrm{P}\left(4150.00 \mathrm{mg} \mathrm{kg}^{-1}\right), \mathrm{K}\left(3403.33 \mathrm{mg} \mathrm{kg}^{-1}\right)$ and $\mathrm{Mg}\left(1210.33 \mathrm{mg} \mathrm{kg}^{-1}\right)$ than in the $\mathrm{N} 1$ and $\mathrm{N} 2$ variant. The highest concentration of $\mathrm{Ca}\left(176.00 \mathrm{mg} \mathrm{kg}^{-1}\right)$ was in the cases when the dose of $60 \mathrm{~kg} \mathrm{~N} \mathrm{ha}^{-1}$ was applied, while the sulphur concentration in $\mathrm{N} 2\left(1007.33 \mathrm{mg} \mathrm{kg}^{-1}\right)$ was higher by approximately $2 \%$ than in the N0 and N1 variants (Fig. 2).
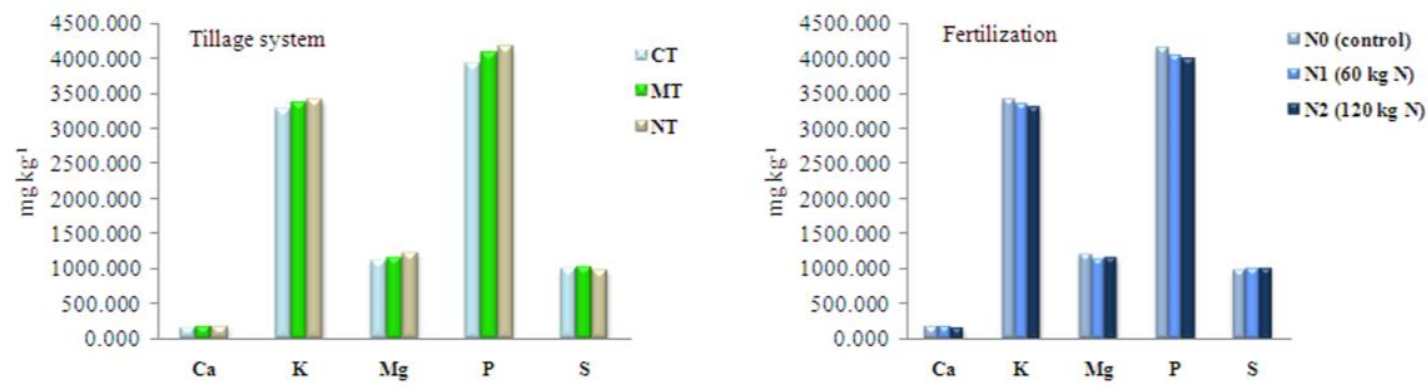

Figure 2. Changes of macroelement concentration $\left(\mathrm{mg} \mathrm{kg}^{-1}\right)$ in the grain within different tillage systems and levels of fertilization 
Observing the interaction between the tillage systems and the levels of nitrogen fertilization, it can be noticed that the highest average value of Ca $\left(189 \pm 4 \mathrm{mg} \mathrm{kg}^{-1}\right)$ was recorded in the NT system with the N0 variant, and it was significantly higher than in other tillage systems and levels of nitrogen fertilization. It is interesting that the differences in the $\mathrm{K}$ concentration were not significant between the CT system with the N0 variant $\left(3652 \pm 34 \mathrm{mg} \mathrm{kg}^{-1}\right)$ and the $\mathrm{NT}$ system with the N2 variant $\left(3627 \pm 11 \mathrm{mg} \mathrm{kg}^{-1}\right)$. On the other hand, the concentrations of $\mathrm{Mg}\left(1300 \pm 7 \mathrm{mg} \mathrm{kg}^{-1}\right), \mathrm{P}$ $\left(4470 \pm 14 \mathrm{mg} \mathrm{kg}^{-1}\right)$ and $\mathrm{S}\left(1031.0 \pm 1.0 \mathrm{mg} \mathrm{kg}^{-1}\right)$ in the CT system with the variant N0 were significantly higher than in other tillage systems and fertilization levels. The obtained results indicate that the reduced tillage and/or application of lower nitrogen rates do not decrease the macroelement contents in the wheat grain (Fig. 2).

\section{Concentration of microelements in the wheat grain}

The total content of microelements in the wheat grain and their average concentrations are presented in Table 2. The research results showed that the microelement content in the grain was affected by the tillage system and fertilization rate, as well as by the interaction of these factors (Table Al). There is a small but significant difference regarding the microelement content between the CT system (103.691 mg kg-1) and NT system (102.048 $\mathrm{mg} \mathrm{kg}^{-1}$ ). Considering the differences between the rates of nitrogen fertilization, it can be noticed that the total content of microelements in the $\mathrm{N} 2$ variant $\left(76.096 \mathrm{mg} \mathrm{kg}^{-1}\right)$ is significantly lower than in $\mathrm{N} 1$ $\left(108.229 \mathrm{mg} \mathrm{kg}^{-1}\right)$ and $\mathrm{N} 0\left(104.880 \mathrm{mg} \mathrm{kg}^{-1}\right)$.

The concentrations of $\mathrm{Al}, \mathrm{Cr}$ and $\mathrm{Hg}$ were below the limit of detection (LOD) in all studied grain samples of Azra cultivar. The concentrations of detected microelements, expressed in $\mathrm{mg} \mathrm{kg}^{-1}$, were in the following order: $\mathrm{Fe}(38.10)>\mathrm{Zn}(27.90)>\mathrm{Mn}$ $(22.26)>\mathrm{Cu}(3.87)>\mathrm{Ba}(2.65)>\mathrm{Sr}(0.83)>\mathrm{V}(0.35)>\mathrm{Ni}(0.29)>\mathrm{As}(0.11)>\mathrm{Co}$ (0.06).

The content of Fe detected in the NT system $\left(46.170 \mathrm{mg} \mathrm{kg}^{-1}\right)$ was significantly higher than in the MT $\left(23.390 \mathrm{mg} \mathrm{kg}^{-1}\right)$ and CT system $\left(44.740 \mathrm{mg} \mathrm{kg}^{-1}\right)$. The highest concentration of $\mathrm{Fe}$ in the amount of $47.330 \mathrm{mg} \mathrm{kg}^{-1}$ was detected in the variant of fertilization with the smaller dose of nitrogen $\left(60 \mathrm{~kg} \mathrm{ha}^{-1}\right)$, while the lowest concentration $\left(20.200 \mathrm{mg} \mathrm{kg}^{-1}\right)$ was detected in the application of nitrogen at the rate of $120 \mathrm{~kg} \mathrm{ha}^{-1}$ (Fig. 3). The interaction of the examined factors indicates that the highest Fe concentration $\left(101.3 \pm 1.0 \mathrm{mg} \mathrm{kg}^{-1}\right)$ was obtained in the NT system with the N0 variant, and it was significantly higher than in other tillage systems and fertilization levels (Table 2).
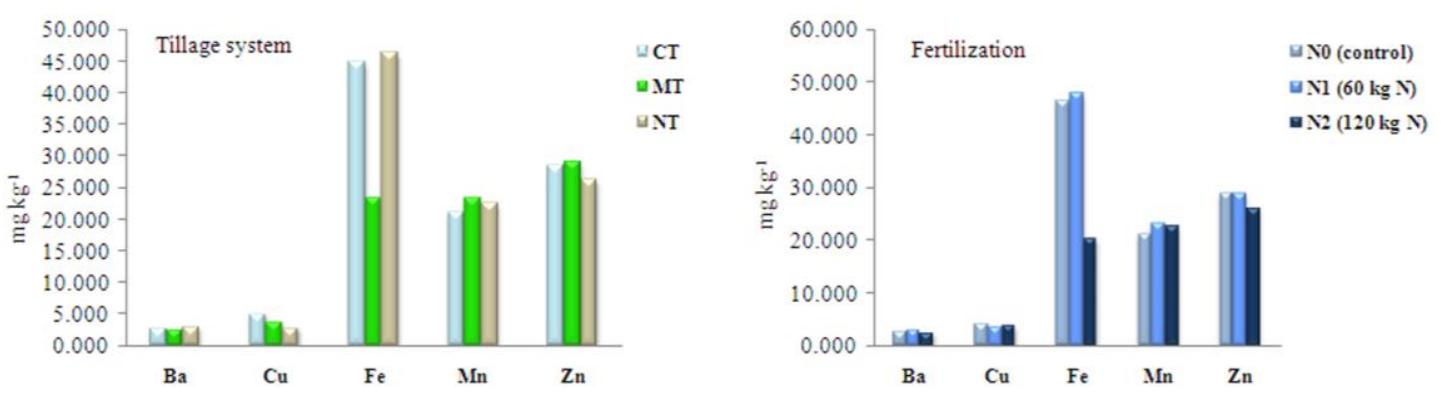

Figure 3. Changes of $\mathrm{Ba}, \mathrm{Cu}, \mathrm{Fe}, \mathrm{Mn}$ and $\mathrm{Zn}$ concentration $\left(\mathrm{mg} \mathrm{kg}^{-1}\right)$ in the grain within different tillage systems and levels of fertilization 
Table 2. Concentration of microelements $\left(\mathrm{mg} \mathrm{kg}^{-1}\right)$ in the wheat grain, $\mathrm{cv}$. Azra

\begin{tabular}{|c|c|c|c|c|c|c|c|c|c|c|c|c|}
\hline Tillage & $\mathrm{N}$ rate & As & $\mathbf{B a}$ & Co & $\mathbf{C u}$ & $\mathbf{F e}$ & Mn & $\mathbf{N i}$ & $\mathbf{S r}$ & $\mathbf{V}$ & $\mathbf{Z n}$ & $\begin{array}{c}\text { Total content } \\
\text { of } \\
\text { microelements }\end{array}$ \\
\hline \multirow{3}{*}{$\mathrm{CT}$} & No & $<\mathrm{LOD}$ & $2.32 \pm 0.02$ & $0.06 \pm 0.02$ & $6.61 \pm 0.06$ & $21.12 \pm 0.07$ & $21.4 \pm 0.3$ & $1.30 \pm 0.09$ & $0.688 \pm 0.005$ & $0.284 \pm 0.002$ & $34.21 \pm 0.06$ & 87.992 \\
\hline & N1 & $0.013 \pm 0.003$ & $2.68 \pm 0.02$ & $0.25 \pm 0.02$ & $2.61 \pm 0.05$ & $96.7 \pm 0.8$ & $22.6 \pm 0.4$ & $0.36 \pm 0.06$ & $0.697 \pm 0.003$ & $0.53 \pm 0.05$ & $29.0 \pm 0.2$ & 155.440 \\
\hline & N2 & $<\mathrm{LOD}$ & $2.97 \pm 0.03$ & $<\mathrm{LOD}$ & $5.98 \pm 0.07$ & $16.4 \pm 0.3$ & $19.3 \pm 0.3$ & $<\mathrm{LOD}$ & $0.79 \pm 0.02$ & $<\mathrm{LOD}$ & $22.2 \pm 0.2$ & 67.640 \\
\hline \multirow{3}{*}{ MT } & N0 & $0.177 \pm 0.004$ & $2.94 \pm 0.05$ & $0.012 \pm 0.003$ & $2.06 \pm 0.06$ & $16.57 \pm 0.09$ & $21.0 \pm 0.4$ & $<\mathrm{LOD}$ & $0.909 \pm 0.008$ & $0.164 \pm 0.003$ & $27.47 \pm 0.10$ & 71.302 \\
\hline & N1 & $<\mathrm{LOD}$ & $3.66 \pm 0.02$ & $0.018 \pm 0.003$ & $6.52 \pm 0.07$ & $28.3 \pm 0.3$ & $24.9 \pm 0.4$ & $0.5 \pm 0.2$ & $0.878 \pm 0.003$ & $0.78 \pm 0.02$ & $31.95 \pm 0.02$ & 97.506 \\
\hline & $\mathrm{N} 2$ & $<\mathrm{LOD}$ & $0.62 \pm 0.03$ & $0.084 \pm 0.010$ & $2.60 \pm 0.05$ & $25.3 \pm 0.4$ & $23.8 \pm 0.3$ & $0.023 \pm 0.004$ & $0.855 \pm 0.004$ & $0.65 \pm 0.04$ & $27.66 \pm 0.07$ & 81.592 \\
\hline \multirow{3}{*}{ NT } & No & $0.24 \pm 0.02$ & $2.459 \pm 0.008$ & $0.050 \pm 0.009$ & $3.84 \pm 0.05$ & $101.3 \pm 1.0$ & $20.8 \pm 0.3$ & $0.171 \pm 0.02$ & $0.905 \pm 0.007$ & $0.38 \pm 0.02$ & $25.2 \pm 0.2$ & 155.345 \\
\hline & N1 & $0.34 \pm 0.03$ & $2.56 \pm 0.02$ & $0.041 \pm 0.006$ & $1.93 \pm 0.05$ & $18.3 \pm 0.2$ & $22.1 \pm 0.2$ & $0.068 \pm 0.002$ & $0.793 \pm 0.004$ & $0.320 \pm 0.005$ & $25.29 \pm 0.05$ & 71.742 \\
\hline & N2 & $0.19 \pm 0.05$ & $3.66 \pm 0.02$ & $0.018 \pm 0.002$ & $2.67 \pm 0.07$ & $18.9 \pm 0.4$ & $24.4 \pm 0.2$ & $0.17 \pm 0.03$ & $0.908 \pm 0.004$ & $<\mathrm{LOD}$ & $28.14 \pm 0.10$ & 79.056 \\
\hline \multirow{3}{*}{ Tillage } & $\mathrm{CT}$ & 0.004 & 2.657 & 0.103 & 5.066 & 44.740 & 21.100 & 0.553 & 0.725 & 0.271 & 28.470 & 103.691 \\
\hline & MT & 0.059 & 2.407 & 0.038 & 3.727 & 23.390 & 23.233 & 0.174 & 0.881 & 0.531 & 29.027 & 83.467 \\
\hline & NT & 0.257 & 2.893 & 0.036 & 2.813 & 46.170 & 22.433 & 0.136 & 0.869 & 0.233 & 26.210 & 102.048 \\
\hline \multirow{3}{*}{ N Rate } & N0 & 0.139 & 2.573 & 0.041 & 4.170 & 46.330 & 21.067 & 0.490 & 0.834 & 0.276 & 28.960 & 104.880 \\
\hline & N1 & 0.118 & 2.967 & 0.103 & 3.687 & 47.770 & 23.200 & 0.309 & 0.789 & 0.543 & 28.747 & 108.229 \\
\hline & N2 & 0.063 & 2.417 & 0.034 & 3.750 & 20.200 & 22.500 & 0.064 & 0.851 & 0.217 & 26.000 & 76.096 \\
\hline
\end{tabular}

$\mathrm{Al}, \mathrm{Cr}$ and $\mathrm{Hg}$ were below LOD; Data are expressed as mean \pm standard deviation $(\mathrm{n}=3)$ 
Significant differences between the tillage systems were also detected regarding the concentration of $\mathrm{Zn}$. In the NT system $\left(26.210 \mathrm{mg} \mathrm{kg}^{-1}\right)$ it was lower by $9.7 \%$ and $7.9 \%$ than in the MT and CT systems, respectively. Considering the variants of nitrogen fertilization, $\mathrm{Zn}$ concentration was significantly lower than in the control, particularly in the $\mathrm{N} 2$ variant $(10.2 \%)$. Observing the interaction of the examined factors, it can be noticed that the highest $\mathrm{Zn}$ concentration was detected in the CT system with the control variant $\left(34.21 \pm 0.06 \mathrm{mg} \mathrm{kg}^{-1}\right)$, in the MT system with the $\mathrm{N} 1$ variant $(31.95 \pm 0.02 \mathrm{mg}$ $\mathrm{kg}^{-1}$ ), and in the NT system with the $\mathrm{N} 2$ variant $\left(28.14 \pm 0.10 \mathrm{mg} \mathrm{kg}^{-1}\right)$ (Table 2).

When it comes to $\mathrm{Mn}$, there were also significant differences regarding the tillage system and fertilization rate. The highest Mn concentration was detected in the MT system $\left(23.233 \mathrm{mg} \mathrm{kg}^{-1}\right)$, and it was higher than in the CT and NT systems by $10.1 \%$ and $3.6 \%$, respectively. The $\mathrm{Mn}$ concentration in the $\mathrm{N} 1$ variant $\left(23.200 \mathrm{mg} \mathrm{kg}^{-1}\right)$ was higher than in the $\mathrm{N} 0$ and $\mathrm{N} 2$ variants by $10.1 \%$ and $3.2 \%$, respectively.

The application of the conventional tillage system resulted in the significantly higher concentrations of $\mathrm{Cu}\left(5.066 \mathrm{mg} \mathrm{kg}^{-1}\right), \mathrm{Ni}\left(0.553 \mathrm{mg} \mathrm{kg}^{-1}\right)$ and $\mathrm{Co}\left(0.103 \mathrm{mg} \mathrm{kg}^{-1}\right)$ than in the NT and MT systems, while there were no significant differences regarding nickel and cobalt between the NT and MT systems. It was also noticed that the concentrations of $\mathrm{Cu}$ and $\mathrm{Ni}$ in the grain decreased with the increased rate of nitrogen fertilization. Therefore, the highest concentrations of these microelements were detected in the variant N0 (4.170 $\mathrm{mg} \mathrm{kg}^{-1}$ and $0.490 \mathrm{mg} \mathrm{kg}^{-1}$ ). The concentration of Co in the wheat grain was the highest when the application of nitrogen was at the rate of $60 \mathrm{~kg} \mathrm{ha}^{-1}$ and the differences between the variants N0 $\left(0.041 \mathrm{mg} \mathrm{kg}^{-1}\right)$ and N2 $\left(0.034 \mathrm{mg} \mathrm{kg}^{-1}\right)$ were not significant.

The highest Ba concentration was detected in the NT system $\left(2.893 \mathrm{mg} \mathrm{kg}^{-1}\right)$, which was higher $(\mathrm{p}<0.05)$ by $20.2 \%$ and $8.9 \%$ than in the MT and CT systems, respectively. Significant differences were also obtained at different fertilization rates. The $\mathrm{Ba}$ concentration in the $\mathrm{N} 2$ variant $\left(2.417 \mathrm{mg} \mathrm{kg}^{-1}\right)$ was lower by $6.1 \%$ and $18.5 \%$ than in the control and $\mathrm{N} 1$ variant, respectively.

The content of $\mathrm{Sr}$ in plants is highly variable. The research results showed that the $\mathrm{Sr}$ concentration in the grain was the lowest in the CT system $\left(0.725 \mathrm{mg} \mathrm{kg}^{-1}\right)$, and it was lower than in the MT and NT system by $17.7 \%$ and $16.5 \%$, respectively. When it comes to the differences in fertilization rates, the lowest $\mathrm{Sr}$ concentration $\left(0.789 \mathrm{mg} \mathrm{kg}^{-1}\right)$ in the grain was detected when applying the dose of $60 \mathrm{~kg} \mathrm{~N} \mathrm{ha}^{-1}$, while its concentration was the highest $\left(0.851 \mathrm{mg} \mathrm{kg}^{-1}\right)$ at the rate of $120 \mathrm{~kg} \mathrm{~N} \mathrm{ha}^{-1}$.

The highest concentrations of V were detected in the MT system $\left(0.531 \mathrm{mg} \mathrm{kg}^{-1}\right)$ and at the nitrogen application at a rate of $60 \mathrm{~kg} \mathrm{ha}^{-1}\left(0.543 \mathrm{mg} \mathrm{kg}^{-1}\right)$. The intensity of soil tillage had an impact on the increase of As content, while the application of $\mathrm{N}$ fertilizers decreased the concentration of this trace element in the wheat grain (Fig. 4).

\section{Discussion}

A high yield of good quality is based on the proper use of agro-technical measures, primarily on the appropriate soil tillage and adapted crop fertilization. In modern agriculture, it is important to understand the effects of these measures since they can affect the product quality (Klikocka and Marks, 2018), and also contribute to the protection and preservation of soil fertility. 

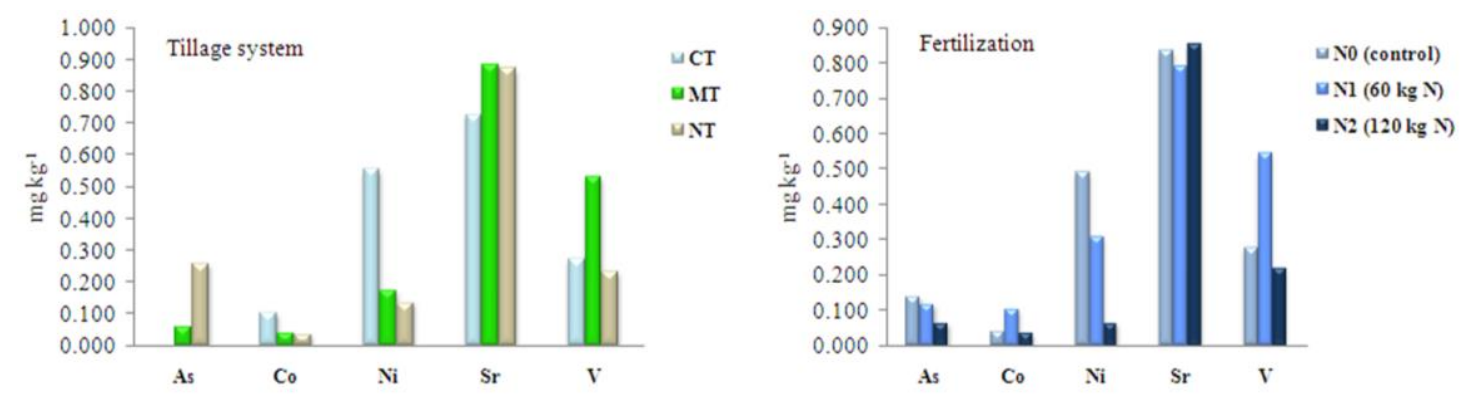

Figure 4. Changes of As, Co, Ni, Sr and V concentration $\left(\mathrm{mg} \mathrm{kg}^{-1}\right)$ in the grain within different tillage systems and levels of fertilization

It was determined that the mineral content in the wheat grain, cv. Azra, differed significantly depending on the tillage system. The grain originating from the NT system had a significantly higher content of macroelements than in the MT system (1.7\%) and CT system (5.3\%). The highest concentrations of Ca (178.67 $\left.\mathrm{mg} \mathrm{kg}^{-1}\right), \mathrm{K}(3410.33 \mathrm{mg}$ $\left.\mathrm{kg}^{-1}\right), \mathrm{Mg}\left(1236.33 \mathrm{mg} \mathrm{kg}^{-1}\right)$ and $\mathrm{P}\left(4167.00 \mathrm{mg} \mathrm{kg}^{-1}\right)$ were detected in the NT system $(\mathrm{p}<0.001)$, while the highest $\mathrm{S}$ concentration $\left(1016.33 \mathrm{mg} \mathrm{kg}^{-1}\right)$ was found in the wheat grain cultivated in the MT system ( $\mathrm{p}$ <.05). The obtained results suggest that the reduced tillage systems can have a positive effect on the concentration of macroelements in the wheat grain. According to De Vita et al. (2007), the NT system is more efficient than the $\mathrm{CT}$ in arid environments since it decreases the evaporation of moisture from soil surface, which ensures its better availability to plants. Furthermore, Wozniak (2010) states that the reduced tillage and lowered rates of $\mathrm{N}$ fertilizers increase the content of minerals in the wheat grain.

Nitrogen has a crucial role in the vegetative growth and crop quality (Faizy et al., 2017; Litke et al., 2018). However, the intensive application of mineral fertilizers has different local and global effects on the environment and human health. The research results have shown that the lowest average concentrations of $\mathrm{Ca}\left(165.33 \mathrm{mg} \mathrm{kg}^{-1}\right), \mathrm{K}$ $\left(3301.33 \mathrm{mg} \mathrm{kg}^{-1}\right)$ and $\mathrm{P}\left(3986.67 \mathrm{mg} \mathrm{kg}^{-1}\right)$ were detected in the variant with the highest rate of nitrogen fertilization $\left(120 \mathrm{~kg} \mathrm{ha}^{-1}\right)$. Studying the nitrogen application in protected areas, Bar-Tal et al. (2001) concluded that the application of larger doses of nitrogen decreased the assimilation of $\mathrm{Ca}$, which is probably a consequence of the increased concentration of $\mathrm{NH}_{4}{ }^{+}$. Other studies showed that higher rates of $\mathrm{N}$ fertilizer application increased the content of phosphorus and potassium in the wheat grain (Gaj and Gorski, 2014; Faizy et al., 2017), which can be affected by numerous factors such as assortment, crop maturity, soil type and content, fertilizer type and rate (Jākobsone et al., 2015; Kan, 2015). In this study, fertilizer application did not have a positive effect on the increase of $\mathrm{Mg}$ concentration in the wheat grain. Nutrition treatment at the $\mathrm{N}$ rates of 60 and $120 \mathrm{~kg} \mathrm{ha}^{-1}$ had similar values of $\mathrm{Mg}$ content, and they were significantly lower than in the control treatment $\left(1210.33 \mathrm{mg} \mathrm{kg}^{-1}\right)$. Considering the studied macroelements, only $\mathrm{S}$ had a detected rise of concentration connected to the increase of N fertilizer dose. Similarly, Jamal et al. (2010) stated that there was a high positive correlation between the nitrogen and sulphur contents in wheat.

The analysis of variance of the obtained results showed that tillage had a statistically significant effect on concentration of microelements in the grain of cv. Azra. The highest $(\mathrm{p}<0.05)$ concentrations of $\mathrm{Fe}\left(46.170 \mathrm{mg} \mathrm{kg}^{-1}\right), \mathrm{Ba}\left(2.893 \mathrm{mg} \mathrm{kg}^{-1}\right)$ and As $\left(0.257 \mathrm{mg} \mathrm{kg}^{-1}\right)$ were detected in NT, while the concentrations of Zn $\left(29.027 \mathrm{mg} \mathrm{kg}^{-1}\right)$, 
Mn (23.233 mg kg-1), Sr $\left(0.881 \mathrm{mg} \mathrm{kg}^{-1}\right)$ and $\mathrm{V}\left(0.531 \mathrm{mg} \mathrm{kg}^{-1}\right)$ in the MT system were significantly higher than in the CT and NT systems (Figs. 3 and 4). Arsenic is an environmental and food-chain contaminant, and inorganic As is a class-one carcinogen (Zhao et al., 2010). Wozniak and Makarski (2012) underline that the availability of microelements in well aerated soils is lower than in the less aerated ones, so it can be concluded that the multiple aeration of ground in the ploughing system depresses the availability of $\mathrm{Zn}$ and $\mathrm{Cu}$, unlike in the ploughless tillage. The assimilation of $\mathrm{Fe}, \mathrm{Cu}$, $\mathrm{Mn}$ and $\mathrm{Zn}$ in the reduced tillage systems is easier not only for wheat but also for weeds in the calcareous soil (Taghizadeh et al. 2014). In addition, Santiago et al. (2008) found out that there was a higher concentration of $\mathrm{Mn}, \mathrm{Cu}$ and $\mathrm{Zn}$ in the plants cultivated in the NT system than in the ones from CT and MT systems. Higher concentration of Mn in the conditions of reduced tillage (23.233 mg kg-1 and $\left.22.433 \mathrm{mg} \mathrm{kg}^{-1}\right)$ than in the case of conventional tillage $\left(21.100 \mathrm{mg} \mathrm{kg}^{-1}\right)$ can be explained by the better moisture content in the soil in MT and NT systems, which was confirmed by other studies (Wozniak and Makarski, 2012). The decrease of mineral content in the food is considered to be related to the intensive agricultural practices which can result in their depletion from the soil (Kan, 2015).

Reduced tillage increases the content of organic matter and preserves soil fertility more than the conventional management practices (De Sanctis et al., 2012). Rizwan et al. (2016) say that organic amendments could be used to reduce the uptake of toxic trace elements by crop plants. The research results have shown that the lowest concentrations of microelements such as $\mathrm{Co}\left(0.036 \mathrm{mg} \mathrm{kg}^{-1}\right), \mathrm{Cu}\left(2.813 \mathrm{mg} \mathrm{kg}^{-1}\right)$ and $\mathrm{Ni}\left(0.136 \mathrm{mg} \mathrm{kg}^{-1}\right)$ were detected in the NT system (Figs. 3 and 4). Other authors also underlined the tendency of heavy metals to make stable compounds with the organic matter and thus lower their bioavailability (Kabata Pendias, 2011).

Understanding the interactions between nitrogen and other elements is the key for the improvement of the efficiency of fertilizer application (Domagała-Świątkiewicz and Gąstoł, 2013). The highest total content of microelements $\left(108.229 \mathrm{mg} \mathrm{kg}^{-1}\right)$ was recorded with the nitrogen application at a dose of $60 \mathrm{~kg} \mathrm{ha}^{-1}$, while the lowest (76.096 mg kg-1) was detected when the dose of $120 \mathrm{~kg} \mathrm{ha}^{-1}$ was applied. Also, the lowest concentrations of $\mathrm{Ba}\left(2.417 \mathrm{mg} \mathrm{kg}^{-1}\right)$, Co $\left(0.034 \mathrm{mg} \mathrm{kg}^{-1}\right), \mathrm{Ni}\left(0.064 \mathrm{mg} \mathrm{kg}^{-1}\right), \mathrm{V}$ $\left(0.217 \mathrm{mg} \mathrm{kg}^{-1}\right), \mathrm{Zn}\left(26.000 \mathrm{mg} \mathrm{kg}^{-1}\right)$ and $\mathrm{Fe}\left(20.200 \mathrm{mg} \mathrm{kg}^{-1}\right)$ were detected when applying the highest nitrogen dose (Figs. 3 and 4). The average Ba concentration in plant tissues ranges between 2 and $13 \mathrm{mg} \mathrm{kg}^{-1}$ and the higher concentrations of $\mathrm{Ba}$ are found in the plants from aridic zones (Kabata Pendias, 2011), whereas V is relatively easily taken up from acid soil, and some studies show that it is related to the process of biological nitrogen fixation (Bjekić, 2014). Fe availability to plants is dictated by the redox potential and $\mathrm{pH}$ soil reaction. In soils of higher $\mathrm{pH}, \mathrm{Fe}$ is oxidized and is mostly in the form of insoluble ferric oxides which are less available to plants (Morrissey and Guerinot, 2009). In this case, the nitrate form of nitrogen (brought by a higher fertilization rate) probably increased $\mathrm{pH}$ and thus lowered the Fe uptake by plants. Zhao et al. (2009) underlined that $\mathrm{Zn}$ and $\mathrm{Fe}$ concentrations were significantly and positively correlated with $\mathrm{P}$ content, which was confirmed in this study since the lowest values of all three elements were detected in the $\mathrm{N} 2$ variant.

On the other hand, numerous authors state that larger doses of $\mathrm{N}$ fertilizer increase the microelement content in wheat, and some of the studies include the combined application of nitrogen and certain microelements (Klikocka and Marks, 2018; Kutman et al., 2011). Years-long research has shown that the application of higher nitrogen rates 
leads to the increase in $\mathrm{Fe}, \mathrm{Zn}$ and $\mathrm{Cu}$ concentrations, but it does not affect $\mathrm{Mn}$ concentration in the wheat grain (Shi et al., 2010). Later studies showed that the applied forms of $\mathrm{N}$ fertilizer had different effects on Mn content in plants (Klikocka and Marks, 2018). Svećnjak et al. (2013) reported that the content of trace elements depended primarily on the bioavailability of the minerals, but that different wheat cultivars could absorb different element levels from the soil, and that the same wheat cultivar could absorb different mineral levels from different soils.

The results have shown that $\mathrm{Ni}$ concentration $\left(0.064 \mathrm{mg} \mathrm{kg}^{-1}\right)$ in the grain was the lowest in the variant with the highest rate of nitrogen application (Fig. 4), which can be the consequence of soil acidity, organic matter content and sorption capacity (Shaheen et al., 2017; Wlasniewski et al., 2019). The study of Wlasniewski et al. (2019) did not record a significant impact of mineral nutrition on the varying of nickel quantities in the wheat and barley grain, but it noticed a certain tendency of reducing the content of this metal in the wheat grain with the increase of NPK dose (Wlasniewski et al., 2019).

\section{Conclusion}

The results of the research have shown that the tillage system and level of nitrogen fertilization in top dressing, as well as the interaction between these two factors had an important effect on the content of macro- and microelements in the grain of winter wheat cultivar Azra. The lowest content of the examined macroelements, as well as the highest concentration of microelements $\mathrm{Co}, \mathrm{Cu}$ and $\mathrm{Ni}$, was observed in the grain produced in the $\mathrm{CT}$ system. On the other hand, the highest concentrations of microelements $\mathrm{Fe}, \mathrm{Ba}$ and As were detected in the grain produced in the NT system. In the grain from the MT system, the concentrations of Mn, Sr, V and Zn were the highest in comparison with two other tillage systems. Significant differences in concentrations of macro- and microelements were detected in the grain produced with different levels of nitrogen fertilization. The highest total content of macroelements, as well as highest concentrations of $\mathrm{Mg}, \mathrm{K}$ and $\mathrm{P}$, was detected in the control. In the grain treated with a smaller dose of nitrogen $\left(60 \mathrm{~kg} \mathrm{ha}^{-1}\right)$, the highest total content of microelements, as well as the highest concentrations of $\mathrm{Co}, \mathrm{Ba}, \mathrm{Fe}, \mathrm{Mn}$ and $\mathrm{V}$, was detected. The obtained results indicated that reduced tillage and/or reduced nitrogen fertilization did not cause the reduction in macroelement content in the grain. Moreover, it had a positive effect on the content of nutritionally important minerals $(\mathrm{Ca}, \mathrm{Cu}, \mathrm{Fe}, \mathrm{K}, \mathrm{Mg}, \mathrm{Mn}, \mathrm{P}$ and $\mathrm{Zn}$ ) in respect to the conventional tillage system with higher levels of nitrogen applied.

Acknowledgements. This work was supported by the Ministry of Education, Science and Technological Development of the Republic of Serbia (Research grants Nos. 31066, 46006 and 46009).

\section{REFERENCES}

[1] Abbas, Q., Yousaf, B., Liu, G., Zia-ur-Rehman, M., Ali, M. U., Munir, M. A. M., Hussain, S. A. (2017): Evaluating the health risks of potentially toxic elements through wheat consumption in multi-industrial metropolis of Faisalabad, Pakistan. Environmental Science and Pollution Research 24(34): 26646-26657.

[2] Bar-Tal, A., Aloni, B., Karni, L., Rosenberg, R. (2001): Nitrogen nutrition of greenhouse pepper. II. Effects of nitrogen concentration and NO3: NH4 ratio on growth, transpiration, and nutrient uptake. - HortScience 36(7): 1252-1259. 
[3] Barunawati, N., Hettwer Giehl, R. F., Bauer, B., Von Wirén, N. (2013): The influence of inorganic nitrogen fertilizer forms on micronutrient retranslocation and accumulation in grains of winter wheat. - Frontiers in Plant Science 4: 320.

[4] Bjekić, D. (2014): Characterization and effectiveness of plant growth promoting bacteria isolated from the rhizosphere of maize. - PhD Thesis, University of Novi Sad Faculty of Agriculture (in Serbian).

[5] Blandino, M., Marinaccio, F., Reyneri, A. (2016): Effect of late-season nitrogen fertilization on grain yield and on flour rheological quality and stability in common wheat, under different production situations. - Italian Journal of Agronomy 11(745): 107113.

[6] Cakmak, I., Pfeiffer, W. H., McClafferty, B. (2010): Biofortification of durum wheat with zinc and iron. - Cereal Chemistry 87: 10-20.

[7] Dapkekar, A., Deshpande, P., Oak, M. D., Paknikar, K. M., Rajwade, J. M. (2018): Zinc use efficiency is enhanced in wheat through nanofertilization. - Scientific Reports 8(1): 6832.

[8] De Sanctis, G., Roggero, P. P., Seddaiu, G., Orsini, R., Porter, C. H., Jones, J. W. (2012): Long-term no tillage increased soil organic carbon content of rain-fed cereal systems in a Mediterranean area. - European Journal of Agronomy 40: 18-27.

[9] De Vita, P., Di Paolo, E., Fecondo, G., Di Fonzo, N., Pisante, M. (2007): No-tillage and conventional tillage effects on durum wheat yield, grain quality and soil moisture content in southern Italy. - Soil and Tillage Research 92(1-2): 69-78.

[10] Domagała-Świątkiewicz, I., Gąstoł, M. (2013): Effect of nitrogen fertilization on the content of trace elements in cv. Bianca grapevine (Vitis sp.). - Journal of Elementology 18(1): 39-53.

[11] Faizy, S. E. D., Mashali, S. A., Youssef, S. M., Elmahdy, M. S. (2017): Study of wheat response to nitrogen fertilization, micronutrients and their effects on some soil available macronutrients. - Journal of Sustainable Agricultural Sciences 43(1): 55-64.

[12] Food and Agriculture Organization of the United Nations (2016): Statistical Yearbook of the Food and Agriculture Organization: Feeding the World. www.fao.org/docrep/018/i3107e/i3107e03.pdf.

[13] Gaj, R., Gorski, D. (2014): Effects of different phosphorus and potassium fertilization on contents and uptake of macronutrients $(\mathrm{N}, \mathrm{P}, \mathrm{K}, \mathrm{Ca}, \mathrm{Mg})$ in winter wheat. - Journal of Central European Agriculture 15(4): 169-187.

[14] Jākobsone, I., Kantāne, I., Zute, S., Jansone, I., Bartkevičs, V. (2015): Macro-elements and trace elements in cereal grains cultivated in Latvia. - Proceedings of the Latvian Academy of Sciences. Section B. Natural, Exact and Applied Sciences 69(4): 152-157.

[15] Jamal, A., Moon, Y. S., Abdin, M. Z. (2010): Sulphur - a general overview and interaction with nitrogen. - Australian Journal of Crop Science 4(7): 523-529.

[16] Kabata-Pendias, A. (2011): Trace Elements in Soils and Plants. Fourth Ed. - CRC, Boca Raton, FL.

[17] Kan, A. (2015): Characterization of the fatty acid and mineral compositions of selected cereal cultivars from Turkey. - Records of Natural Products 9(1): 124.

[18] Klikocka, H., Marx, M. (2018): Sulphur and nitrogen fertilization as a potential means of agronomic biofortification to improve the content and uptake of microelements in spring wheat grain DM. - Journal of Chemistry 2018: 1-12.

[19] Korunović, R., Stojanović, S. (1989): Praktikum iz pedologije. - Poljoprivredni Fakultet, Beograd.

[20] Kutlu, I. (2018): Heritability of end-use quality and biofortification characteristics in line $\mathrm{x}$ tester bread wheat (Triticum aestivum L.) crosses. - Applied Ecology and Environmental Research 16(5): 7305-7326.

[21] Kutman, U. B., Yildiz, B., Cakmak, I. (2011): Effect of nitrogen on uptake, remobilization and partitioning of zinc and iron throughout the development of durum wheat. - Plant Soil 342: 149-164. 
[22] Lei, M., Tie, B. Q., Song, Z. G., Liao, B. H., Lepo, J. E., Huang, Y. Z. (2015): Heavy metal pollution and potential health risk assessment of white rice around mine areas in Hunan Province, China. - Food Security 7: 45-54.

[23] Litke, L., Gaile, Z., Ruža, A. (2018): Effect of nitrogen fertilization on winter wheat yield and yield quality. - Agronomy Research 16(2): 500-509.

[24] Morrissey, J., Guerinot, M. L. (2009): Iron uptake and transport in plants: the good, the bad, and the ionome. - Chemical Reviews 109(10): 4553-4567.

[25] Popović Djordjević, J., Marjanović, Ž. S., Gršić, N., Adžić, T., Popović, B., Bogosavljević, J., Brčeski, I. (2019): Essential elements as a distinguishing factor between mycorrhizal potentials of two cohabiting truffle species in riparian forest habitat in Serbia. - Chemistry and Biodiversity. https://doi.org/10.1002/cbdv.201800693.

[26] Rizwan, M., Ali, S., Abbas, T., Zia-ur-Rehman, M., Hannan, F., Keller, C., ... and Ok, Y. S. (2016): Cadmium minimization in wheat: a critical review. - Ecotoxicology and Environmental Safety 130: 43-53.

[27] Santiago, A. D., Quintero, J. M., Delgado, A. (2008): Long-term effects of tillage on the availability of iron, copper, manganese, and zinc in a Spanish vertisol. - Soil and Tillage Research 98(2): 200-207.

[28] Shaheen, S. M., Antić-Mladenović, S., Wang, S. L., Niazi, N. K., Tsadilas, C. D., Ok, Y. S., Rinklebe, J. (2017): Nickel Mobilization/Immobilization and Phytoavailability in Soils as Affected by Organic and Inorganic Amendments. - In: Tsadilas, C., Rinklebe, J., Selim, J. (eds.) Nickel in Soils and Plants. CRC Press, Boca Raton, FL, pp. 283-310.

[29] Sharma, P., Abrol, V., Sharma, R. K. (2011): Impact of tillage and mulch management on economics, energy requirement and crop performance in maize-wheat rotation in rainfed subhumid inceptisols, India. - European Journal of Agronomy 34(1): 46-51.

[30] Shi, R., Zhang, Y., Chen, X. et al. (2010): Influence of long-term nitrogen fertilization on micronutrient density in grain of winter wheat (Triticum aestivum L.). - Journal of Cereal Science 51(1): 165-170.

[31] Singh, B. R., Timsina, Y. N., Lind, O. C., Cagno, S., Janssens, K. (2018): Zinc and iron concentration as affected by nitrogen fertilization and their localization in wheat grain. Frontiers in Plant Science 9: 307.

[32] Stanislawska-Glubiak, E., Korzeniowska, J. (2012): Effect of soil tillage systems on nutrient concentration in winter wheat plants. - Journal of Food, Agriculture \& Environment 10(2): 1353-1355.

[33] Svećnjak, Z., Jenel, M., Bujan, M., Vitali, D., Dragojević, I. V. (2013): Trace element concentrations in the grain of wheat cultivars as affected by nitrogen fertilization. Agricultural and Food Science 22(4): 445-451.

[34] Taghizadeh, M. S., Najafi-Ghiri, M., Omidi, S. (2014): Effect of tillage system and nitrogen on micronutrient uptake by wheat and weeds grown in a calcareous soil. $19^{\text {th }}$ Australasian Weeds Conference. - Science, Community and Food Security: the Weed Challenge. Baker, M., Hobart (ed.), Tasmania, Australia, 1-4 September, pp. 434-436.

[35] Tiwari, S., Lata, C. (2018): Heavy metal stress, signaling and tolerance due to plantassociated microbes: an overview. - Frontiers in Plant Science 9: 1-12.

[36] USDA (2017): Serbia: Grain and Feed Annual. https://gain.fas.usda.gov/Recent\%20GAIN\%20Publications/Grain\%20and\%20Feed $\% 20$ Annual_Belgrade_Serbia_3-31-2017.pdf.

[37] Winiarska-Mieczan, A., Kowalczuk-Vasilev, E., Kwiatkowska, K., Kwiecień, M., Baranowska-Wójcik, E., Kiczorowska, B., ... Samolińska, W. (2019): Dietary intake and content of $\mathrm{Cu}, \mathrm{Mn}, \mathrm{Fe}$, and $\mathrm{Zn}$ in selected cereal products marketed in Poland. Biological Trace Element Research 187(2): 568-578.

[38] Wlasniewski, S., Nazarkiewicz, M., Hajduk, E., Marchel, M., Kaniuczak, J. (2019): Nickel content in grain of winter wheat (Triticum aestivum L.) and spring barley (Hordeum vulgare L.) cultivated on loessial soil, depending on liming and mineral fertilization. - Journal of Elementology 24(1): 257-266. 
[39] Wozniak, A. (2010): Effect of chemical plant protection on grain quality of spring wheat. - Progr. Plant Protect 50(2): 1010-1013. (in Polish).

[40] Wozniak, A., Makarski, B. (2012): Content of minerals in grain of spring wheat cv. Koksa depending on cultivation conditions. - Journal of Elementology 17(3).

[41] Zhang, W. P., Qian, J., Xu, G. J., Zhang, D. M., Kang, C., Feng, D. X., Shi, L., Zhang, C. L., Guo, Z. Y., Ma, J. H., Zhang, C. S (2019): Characterization and evaluation of heavy metal pollution in soil-wheat system around coal mines in Pingdingshan, China. Applied Ecology and Environmental Research 17(3): 5435-5447.

[42] Zhao, F. J., Stroud, J. L., Eagling, T., Dunham, S. J., McGrath, S. P., Shewry, P. R. (2010): Accumulation, distribution, and speciation of arsenic in wheat grain. Environmental Science \& Technology 44: 5464-5468.

[43] Zhao, F. J., Su, Y. H., Dunham, S. J., Rakszegi, M., Bedo, Z., McGrath, S. P., Shewry, P. R. (2009): Variation in mineral micronutrient concentrations in grain of wheat lines of diverse origin. - Journal of Cereal Science 49(2): 290-295.

\section{APPENDIX}

Table A1. Statistical analysis of element concentration in the grain of the winter wheat $\mathrm{cv}$. Azra

\begin{tabular}{|c|c|c|c|c|c|c|}
\hline Source & Element & df & Mean square & $\mathbf{F}$ & Sig. & LSD 0.05 \\
\hline \multirow{17}{*}{ Tillage } & As & 2 & 0.154 & 362.664 & 0.000 & 0.020 \\
\hline & $\mathrm{Ba}$ & 2 & 0.532 & 752.796 & 0.000 & 0.026 \\
\hline & Co & 2 & 0.013 & 117.656 & 0.000 & 0.011 \\
\hline & $\mathrm{Cu}$ & 2 & 11.561 & 3261.705 & 0.000 & 0.059 \\
\hline & $\mathrm{Mn}$ & 2 & 10.453 & 102.261 & 0.000 & 0.317 \\
\hline & $\mathrm{Ni}$ & 2 & 0.522 & 88.627 & 0.000 & 0.076 \\
\hline & $\mathrm{V}$ & 2 & 0.194 & 354.068 & 0.000 & 0.023 \\
\hline & $\mathrm{Zn}$ & 2 & 19.942 & 1198.658 & 0.000 & 0.128 \\
\hline & $\mathrm{Sr}$ & 2 & 0.068 & 1006.157 & 0.000 & 0.008 \\
\hline & $\mathrm{Ca}$ & 2 & 988.000 & 111.150 & 0.000 & 2.951 \\
\hline & $\mathrm{Fe}$ & 2 & 1464.952 & 6012.113 & 0.000 & 0.489 \\
\hline & $\mathrm{K}$ & 2 & 121440.704 & 6.194 & 0.009 & 26.405 \\
\hline & $\mathrm{Mg}$ & 2 & 35356.333 & 103.280 & 0.000 & 18.316 \\
\hline & $\mathrm{P}$ & 2 & 136254.333 & 625.658 & 0.000 & 14.609 \\
\hline & $\mathrm{S}$ & 2 & 2858.333 & 160.781 & 0.000 & 4.174 \\
\hline & $\begin{array}{l}\text { Total content of } \\
\text { microelements }\end{array}$ & 2 & 1135.636 & 1022.625 & 0.000 & 1.043 \\
\hline & $\begin{array}{l}\text { Total content of } \\
\text { macroelements }\end{array}$ & 2 & 607921.000 & 146.041 & 0.000 & 63.87 \\
\hline \multirow{8}{*}{ N_rate } & As & 2 & 0.013 & 30.723 & 0.000 & 0.020 \\
\hline & $\mathrm{Ba}$ & 2 & 0.723 & 1022.287 & 0.000 & 0.026 \\
\hline & Co & 2 & 0.013 & 116.592 & 0.000 & 0.011 \\
\hline & $\mathrm{Cu}$ & 2 & 0.621 & 175.213 & 0.000 & 0.059 \\
\hline & $\mathrm{Mn}$ & 2 & 10.643 & 104.120 & 0.000 & 0.317 \\
\hline & $\mathrm{Ni}$ & 2 & 0.408 & 69.313 & 0.000 & 0.076 \\
\hline & $\mathrm{V}$ & 2 & 0.219 & 399.735 & 0.000 & 0.023 \\
\hline & $\mathrm{Zn}$ & 2 & 24.569 & 1476.780 & 0.000 & 0.128 \\
\hline
\end{tabular}




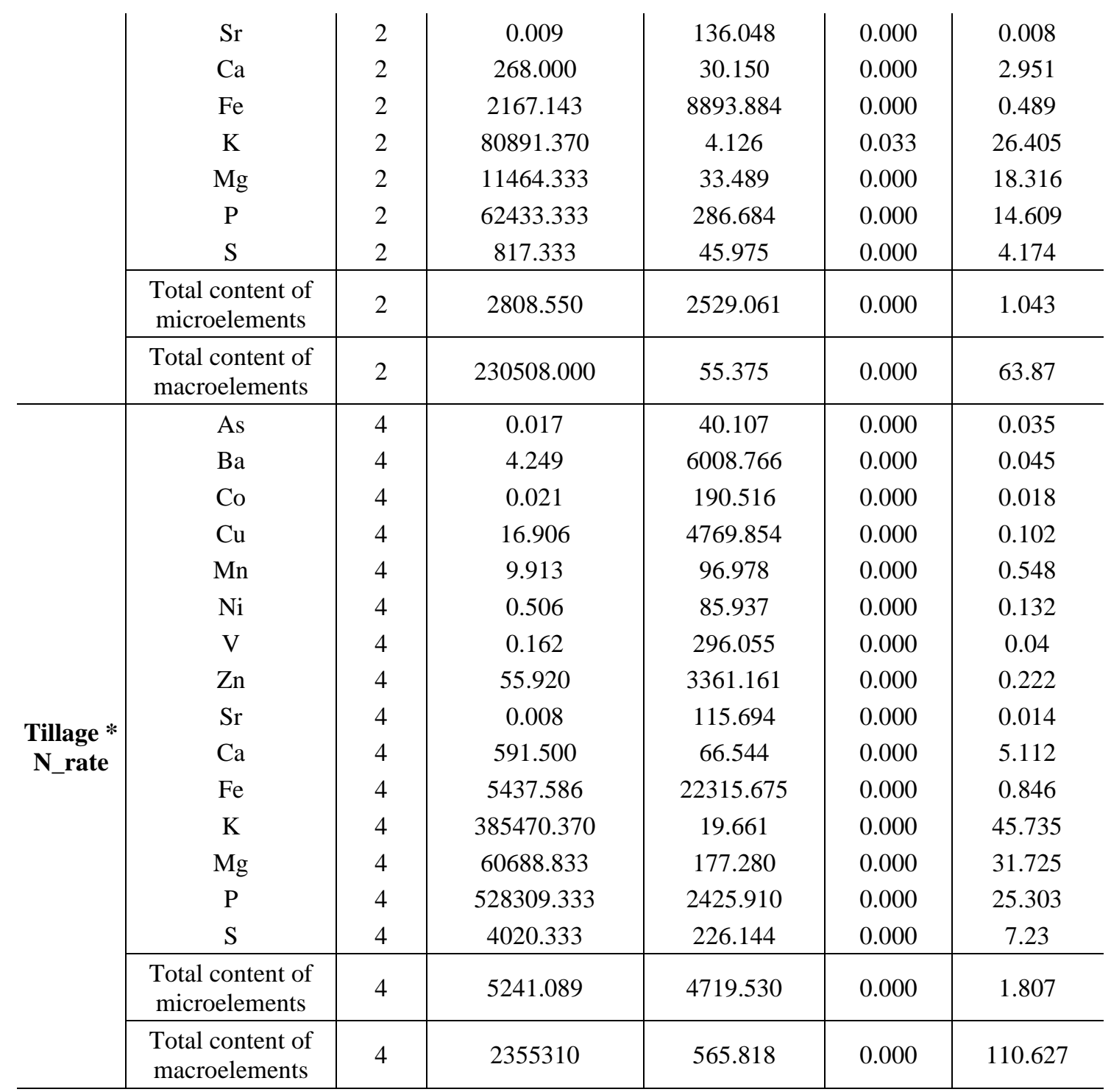

